Article

\title{
Analysis of Ecosystem Service Trade-Offs and Synergies in Ulansuhai Basin
}

\author{
Lina Wang ${ }^{1,2}$, Enyi $\mathrm{Yu}^{1}$, Shuang $\mathrm{Li}^{1,2}{ }^{1}, \mathrm{Xiao} \mathrm{Fu}^{1, *}$ and Gang $\mathrm{Wu}^{1,2}$ \\ 1 State Key Laboratory of Urban and Regional Ecology, Research Center for Eco-Environmental Sciences, \\ Chinese Academy of Sciences, Beijing 100085, China; linwang_st@rcees.ac.cn (L.W.); eyyu@rcees.ac.cn (E.Y.); \\ lishuang_1216@126.com (S.L.); wug@rcees.ac.cn (G.W.) \\ 2 University of Chinese Academy of Sciences, Beijing 100049, China \\ * Correspondence: xiaofu@rcees.ac.cn
}

Citation: Wang, L.; Yu, E.; Li, S.; Fu, X.; Wu, G. Analysis of Ecosystem Service Trade-Offs and Synergies in Ulansuhai Basin. Sustainability 2021, 13, 9839. https://doi.org/10.3390/ su13179839

Academic Editor: J.B. Ruh

Received: 16 July 2021

Accepted: 31 August 2021

Published: 1 September 2021

Publisher's Note: MDPI stays neutral with regard to jurisdictional claims in published maps and institutional affiliations.

Copyright: (c) 2021 by the authors. Licensee MDPI, Basel, Switzerland. This article is an open access article distributed under the terms and conditions of the Creative Commons Attribution (CC BY) license (https:// creativecommons.org/licenses/by/ $4.0 /)$.

\begin{abstract}
As an important grain production base and ecological barrier zone in China, Ulansuhai Basin provides a variety of important ecosystem services and ensures human well-being, and it is essential to maintain the sustainable development of the regional ecology-economy-society. Therefore, in order to explore the trade-offs and synergies between ecosystem services in Ulansuhai Basin, we first evaluated the spatio-temporal characteristics of five ecosystem services in 2000, 2005, 2010, 2015, and 2018 based on the InVEST model, including soil conservation, carbon storage, water production, water purification, and food supply. We then further analyzed the trade-offs and synergies of ecosystem services in Ulansuhai Basin and in different functional areas through using the Spearman correlation coefficient. The results show that different ecosystem services had obvious regional differences due to different land-use types in Ulansuhai Basin. Soil conservation, carbon storage, and water production were higher in the eastern region and lower in the central and western regions, while water purification and food supply were higher in the central region and lower in the eastern and western regions. Ecosystem services showed an overall increasing trend from 2000 to 2018. Moreover, trade-off was the dominant relationship between different ecosystem services, and trade-offs and synergies showed strengthening trends to a certain extent. The trade-offs and synergies of ecosystem services in different functional areas were obviously different. Our study aimed to clarify the trade-offs and synergies between ecosystem services and to propose ecological protection and management countermeasures and suggestions, which can provide decision-making reference for regional ecological protection and management.
\end{abstract}

Keywords: ecosystem services; InVEST model; trade-offs; synergies; basin management

\section{Introduction}

Ecosystem services (ESs) are the natural environmental conditions and effects formed and maintained by ecosystems and ecological processes, as well as the benefits directly or indirectly derived from the ecosystem, upon which humans and other organisms depend [1]. As the link and bridge between ecosystems and social systems [2,3], ecosystem services are closely related to human wellbeing [4,5]. However, with the intensification of global climate change and increasing human activities, regional ecosystem service functions have undergone significant changes, affecting the sustainable development of regional ecology, economy, and society [6,7]. Especially, when human disturbance exceeds the tolerance of the ecosystem, the stability of the ecosystem structure can be destroyed, leading to ecological and environmental problems such as habitat fragmentation and ecosystem function degradation [8]. Therefore, the study of ecosystem service evaluation and its trade-offs and synergies have become the focus of many scholars.

However, related research has mostly focused on the spatial interaction of ecosystem services and their manifestations $[9,10]$. The types of ecosystem services are diverse, and all types of ecosystem services are interrelated, which often reflects in their synergistic 
and trade-offs relationships [11]. There are various types of ecosystem services, and the relationships between various services are mainly trade-offs, synergy, and irrelevance [12]. The geography and ecology theories are mainly used to conduct qualitative analysis of the synergistic and trade-offs relationships of ecosystem services in the current research; there are few studies on the quantification of the benefits of ecosystem services $[13,14]$. The research methods commonly adopted by scholars at home and abroad mainly include statistical description [15], spatial mapping, scenario simulation, and model quantification [16-18]. Jointly developed by Stanford University and other institutions, the InVEST model is relatively mature, so it is widely used now. The InVEST model realizes the integration and trade-offs analysis of multiple ecosystem services by predicting changes in ecosystem services under different land use scenarios [19]. Fu et al. [20] explored the trade-offs relationship of ecosystem services and the method of regional integration, and they analyzed the relationship between land use change and ecosystem services. Tolessa et al. explored the impact of land use and land cover changes on ecosystem services in the central highlands of Ethiopia from 1973 to 2015 [21]. Li et al. [22] quantified the long-term effects of large-scale afforestation on soil erosion and sandstorm prevention in semiarid areas of China.

Different researchers have achieved certain results in the study of the trade-offs and synergies of ecosystem services [23]. The general method is to analyze the relationship between different services by evaluating them and by subsequently putting forward suggestions to solve the main problems in the study area [24]. In recent years, the research on synergistic and trade-offs relationships have been mostly based on quantitative analysis, but they have lacked analysis of the long-term dynamic trend of their relationship with ecological services. There is also a lack of systematic research on the driving mechanism of ecological service changes, especially on the impact of natural or human factors. There are a lot of researchers assessing the ecosystem services of basins by quantitative analysis [22], but the studied ecosystem services have been limited, and there are few studies on the trade-offs and synergies between ecosystem services in basins [25].

As a complete geographic unit, a basin is a typical composite ecosystem, providing a variety of ecosystem services for humans [26]. The Ulansuhai Basin is an important grain production base and ecological barrier zone in China that provides various important ecosystem services such as food supply, soil conservation, water conservation, etc. However, the trade-offs and synergies between different ecosystem services have not been studied and explained in depth. Therefore, taking the Ulansuhai Basin as a case study, we first evaluated the spatio-temporal characteristics of soil conservation, carbon storage, water production, water purification, and food supply from 2000 to 2018 based on the InVEST model. We then used Spearman rank correlation coefficients to analyze the trade-offs and synergies between ecosystem services in Ulansuhai Basin and different functional areas. Consequently, we propose ecological protection and management measures. This research aimed to provide decision-making reference for ecological protection and management, which is of significance for improving ecosystem service functions and achieving regional sustainable development.

\section{Materials and Methods}

\subsection{Study Area}

Ulansuhai is located in Wulateqianqi, Bayannaoer City, Inner Mongolia, China. It is one of the eight largest freshwater lakes in China and one of the rare large grassland lakes in desert and semi-desert areas in the world [27-29], with an area of about $300 \mathrm{~km}^{2}$ and a storage capacity of about 300 million $\mathrm{m}^{3}$ [30]. The Ulansuhai Basin includes the entire Hetao Irrigation District, the Ulansuhai, the Urad Front Banner, the Urad Central Banner, the south of Yinshan Mountain of Urad Rear Banner, and part of Dengkou County. It ranges from $115^{\circ} 25^{\prime} \mathrm{E}$ to $117^{\circ} 30^{\prime} \mathrm{E}$ longitude and from $39^{\circ} 28^{\prime} \mathrm{N}$ to $41^{\circ} 05^{\prime} \mathrm{N}$ latitude, covering a total area of about $16,300 \mathrm{~km}^{2}$ (Figure 1). The Ulansuhai Basin is located in the middle latitude and is a typical temperate continental monsoon climate zone. The average 
annual precipitation is only $174.7 \mathrm{~mm}$, but the annual evaporation is up to $1992-2351 \mathrm{~mm}$, belonging to a typical water-deficient area.

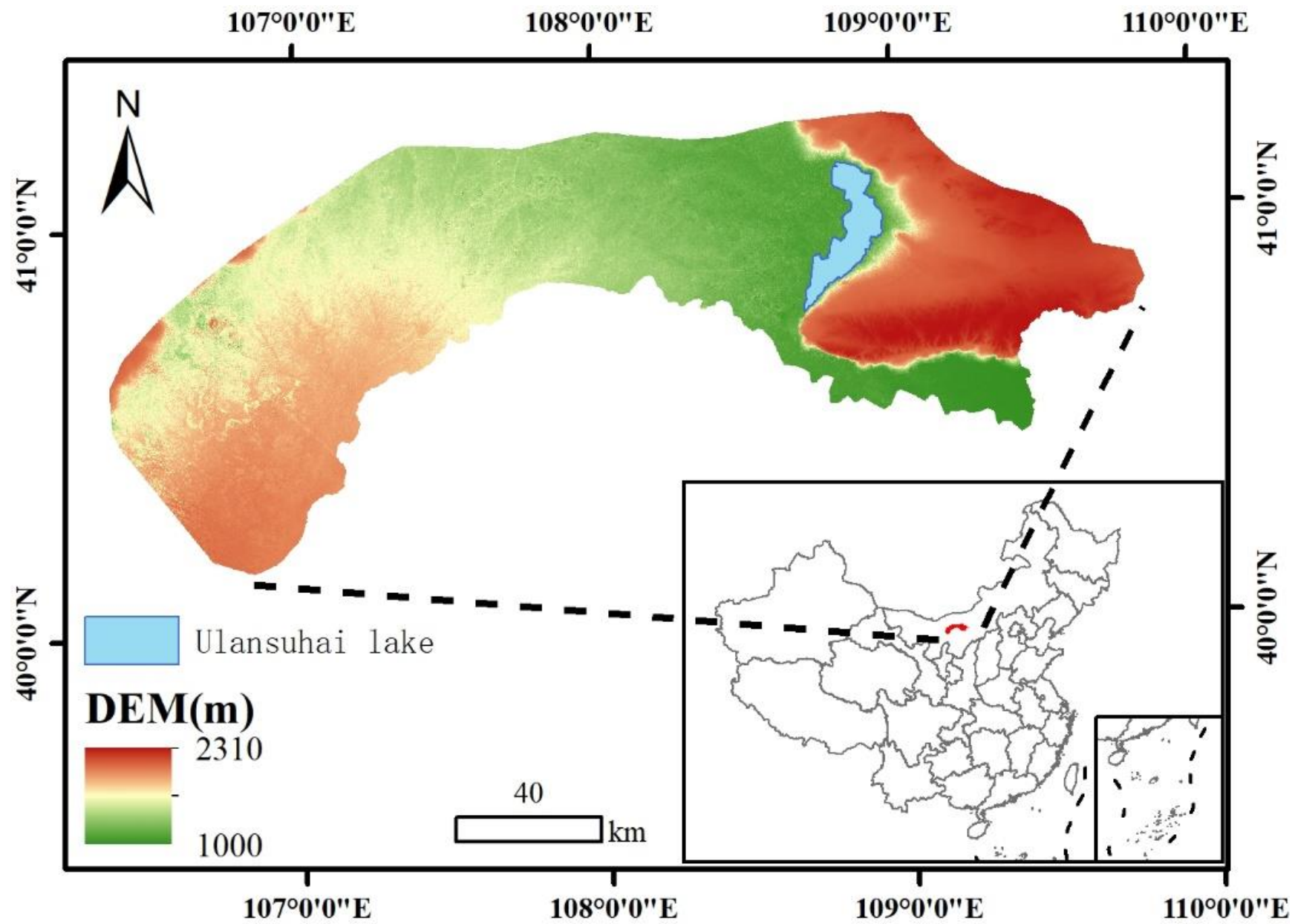

Figure 1. Study area.

There are multiple ecological elements including mountains, rivers, forests, farmland, lakes, grasslands, and deserts in the Ulansuhai basin. Among them, the area of farmland in 2018 reached $7316.46 \mathrm{~km}^{2}$, and the average annual grain output reaches 3.6 million tons, which is an important grain production base in China. As an important part of the water conservancy project in the Hetao Irrigation District, Ulansuhai provides a guarantee for agricultural irrigation water. The grassland area reaches $4509.21 \mathrm{~km}^{2}$, providing important ecosystem service functions such as soil conservation and water conservation.

\subsection{Data Source}

The data sources used in this study mainly included four types. (1) Daily precipitation data of various weather stations in Ulansuhai Basin from 2000 to 2018 were derived from the China Meteorological Data Service Center (http:/ / data.cma.cn/, accessed on 1 July 2021); an annual precipitation raster was obtained by cumulative calculation and spatial interpolation. (2) A digital elevation model (DEM) and land-use data with $30 \mathrm{~m}$ spatial resolution were downloaded from Geospatial Data Cloud (http://www.gis-cloud.cn/). (3) The Chinese soil data set with $1000 \mathrm{~m}$ spatial resolution is available from the Harmonized World Soil Database (HWSD, http:/ /westdc.westgis.ac.cn/). (4) NDVI raster data with $30 \mathrm{~m}$ spatial resolution was obtained from the Resource and Environment Science and Data Center of Chinese Academy of Sciences (http://www.gis-cloud.cn/). (5) The forestry and animal husbandry output data were obtained from the Inner Mongolia Statistical Yearbook (http:/ / tj.nmg.gov.cn/). 


\subsection{Method}

\subsubsection{Ecosystem Service Assessment}

The InVEST model can break through the limitations of traditional quantitative evaluation methods and is a new technical means for the spatial performance, dynamic analysis, and quantitative evaluation of ecosystem service functions. Therefore, this research is based on the InVEST model [31]; four kinds of ecosystem services, including water production, carbon storage, water purification, and soil conservation, were calculated $[3,14]$. Furthermore, the food supply service was calculated based on the statistical yearbook, land-use, and NDVI data [32].

Water production was based on the principle of water balance, calculated by subtracting the actual annual evapotranspiration from the annual precipitation:

$$
Y_{x j}=\left(1-\frac{A E T_{x}}{P_{x}}\right) \times P_{x}
$$

where $A E T_{x j}$ is the actual annual evapotranspiration of grid cell $x, P_{x}$ is the annual precipitation (mm) of grid cell $x$, and $\frac{A E T_{x j}}{P_{x}}$ is the vegetation evapotranspiration of different land-use/land-cover types. The calculation methods and parameters of each factor above can be found in [33-36].

The carbon storage refers to the sum of different vegetation type areas multiplied by the average carbon density of different carbon pools [37-41] as follows:

$$
C_{\text {total }}=C_{\text {above }}+C_{\text {below }}+C_{\text {soil }}+C_{\text {dead }}
$$

where $C_{\text {total }}$ is the total carbon storage of the basin, $C_{\text {above }}$ is the aboveground biomass carbon storage, $C_{\text {below }}$ is the underground biomass carbon storage, $C_{\text {soil }}$ is the soil carbon storage, and $C_{\text {dead }}$ is the dead organic carbon storage.

The purification function of the ecosystem cover type on nitrogen and phosphorus can be evaluated by the water purification module [42]. Specifically, this function is calculated using the amount of nutrients carried by the soil and vegetation in the process of removing runoff,

$$
\operatorname{modified.load}(x, i)=\operatorname{load}(x, i) \times \frac{R P_{i}}{R P_{a v i}}
$$

where modified.load $(x, i)$ denotes the pollutant load value of grid $i$ adjusted to the current situation of the study area, $\operatorname{load}(x, i)$ is the pollutant load value of grid $i, R P_{i}$ is the runoff coefficient of grid $i$, and $R P_{a v}$ is the average runoff coefficient in the study area.

The soil conservation is the difference between potential soil erosion and actual soil erosion,

$$
S D=R \times K \times L S \times(1-C \times P)
$$

where $R$ is the rainfall erosivity factor, $K$ is the soil erodibility factor, $L S$ is the slope length and slope factor, $C$ is the cover and management factor, and $P$ is the soil conservation measure factor. The calculation methods and parameters for each factor can be found in [34].

The food supply refers to the revised result of the total amount of various agricultural products and livestock products provided by arable land and grassland.

$$
F S=G_{\text {sum }} \times \frac{N D V I_{i}}{N D V I_{\text {sum }}}
$$

where FS is the total output of various types of food $\left(\mathrm{t} / \mathrm{km}^{2}\right), G_{\text {sum }}$ is the total amount of various agricultural products and animal husbandry products provided by farmland and grassland, $N D V I_{i}$ denotes the normalized vegetation index for farmland and grassland grids, and $N D V I_{\text {sum }}$ is the sum of NDVI of Ulansuhai Basin.

\subsubsection{Ecosystem Service Trade-Offs Analysis}

With reference to related research $[43,44]$, based on the five ecosystem service raster data from 2000 to 2018, the Create Random Points tool of the GIS software was used to generate 3000 random points in the Ulansuhai basin, and evenly distributed points were obtained. The Spearman correlation coefficient was used to judge the synergy and trade- 
offs relationship between ecosystem services in different functional areas. When $r>0$ and $p<0.05$, the two variables are in a synergistic relationship (i.e., they change in the same direction), while $r<0$ and $p<0.05$ indicates a trade-offs relationship (i.e., they change in the opposite direction). If they are not related $(r=0, p<0.05)$, the relationship is neutral. The size of the value reflects the strength of the relationship between the variables.

\section{Results}

\subsection{Land Use Change}

Farmland, grassland, and unused land were the main land-use types of the basin from 2000 to 2018 , which accounted for $35-45 \%, 27-32 \%$, and $14-20 \%$ of the study area (Table 1 ), respectively. Generally, the areas of different land-use types showed different degrees of change. The area of farmland increased significantly from 2005 to 2010, then stabilized until 2018. Grassland, construction land, and unused land continuously decreased over the whole study period; for water bodies and woodland, there was no change before 2015, but they increased in 2018.

Table 1. Changes in land-use area from 2000 to $2018\left(\mathrm{~km}^{2}\right)$.

\begin{tabular}{cccccc}
\hline Land-Use Types & $\mathbf{2 0 0 0}$ & $\mathbf{2 0 0 5}$ & $\mathbf{2 0 1 0}$ & $\mathbf{2 0 1 5}$ & $\mathbf{2 0 1 8}$ \\
\hline Farmland & 5763.59 & 5852.73 & 7515.27 & 7483.34 & 7316.46 \\
Woodland & 208.09 & 211.76 & 208.30 & 209.84 & 448.13 \\
Grassland & 5312.52 & 5155.78 & 4487.05 & 4500.42 & 4509.21 \\
Water bodies & 628.20 & 610.44 & 607.17 & 645.31 & 821.22 \\
Construction land & 1188.52 & 1199.51 & 730.63 & 759.45 & 829.87 \\
Unused land & 3150.09 & 3220.82 & 2702.67 & 2652.71 & 2332.10 \\
\hline
\end{tabular}

\subsection{Spatiotemporal Changes of Ecosystem Services}

\subsubsection{Soil Conservation}

The total amounts of soil conservation in Ulansuhai Basin in the five phases were $2.4 \times 10^{8} \mathrm{t}, 2.5 \times 10^{8} \mathrm{t}, 2.8 \times 10^{8} \mathrm{t}, 3.5 \times 10^{8} \mathrm{t}$, and $5.0 \times 10^{8} \mathrm{t}$, respectively, from 2000 to 2018 (Table 2), with the total soil conservation having increased by $106.5 \%$. Generally, the soil conservation services were mainly provided by farmland, grassland, and woodland, occupying a relatively high area with a relatively stable state. On the other hand, woodland generated the highest soil conservation per unit area, followed by grassland, while unused land was the lowest.

Table 2. Soil conservation of different land use types in different periods $\left(10^{8} \mathrm{t}\right)$.

\begin{tabular}{cccccc}
\hline Land-Use Types & $\mathbf{2 0 0 0}$ & $\mathbf{2 0 0 5}$ & $\mathbf{2 0 1 0}$ & $\mathbf{2 0 1 5}$ & $\mathbf{2 0 1 8}$ \\
\hline Farmland & 0.48 & 0.52 & 0.53 & 0.71 & 0.79 \\
Woodland & 0.41 & 0.43 & 0.46 & 0.60 & 1.22 \\
Grassland & 1.42 & 1.43 & 1.70 & 2.03 & 2.78 \\
Water bodies & 0.02 & 0.02 & 0.03 & 0.03 & 0.05 \\
Construction land & 0.03 & 0.04 & 0.03 & 0.04 & 0.04 \\
Unused land & 0.04 & 0.05 & 0.07 & 0.08 & 0.07 \\
Total & 2.4 & 2.5 & 2.8 & 3.5 & 5.0 \\
\hline
\end{tabular}

The amount of soil conservation per unit area in Ulansuhai Basin showed an overall growth trend. The high values were concentrated in the woodland and grassland in the east of the basin, while the low values were mainly distributed in the farmland in the middle and the sandy land in the west (Figure 2). 

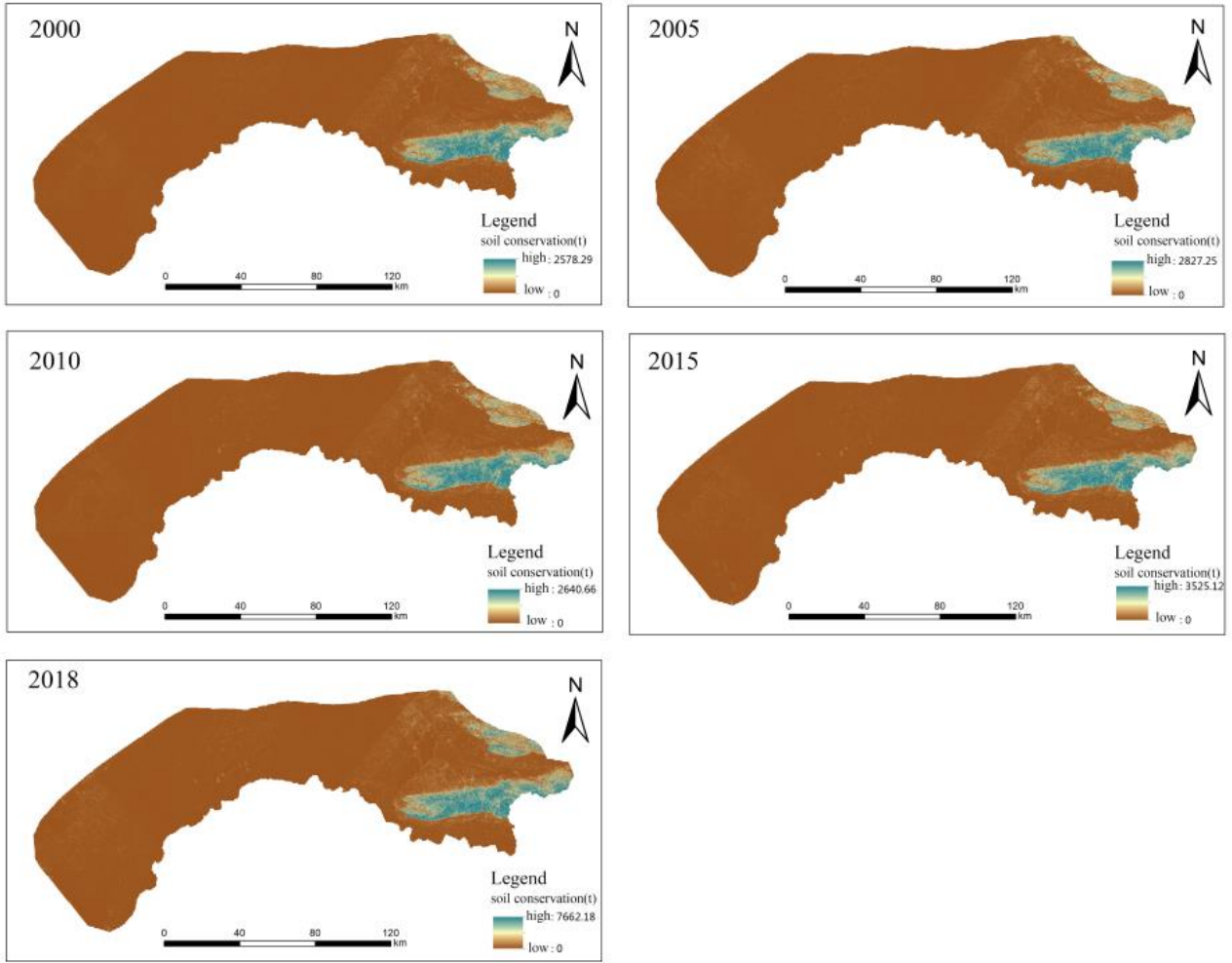

Figure 2. Spatial distribution of soil conservation in the study area from 2000 to 2018.

\subsubsection{Carbon Storage}

The total amounts of carbon storage in the five phases of Ulansuhai Basin were $68.29 \times 10^{6} \mathrm{t}, 67.88 \times 10^{6} \mathrm{t}, 73.28 \times 10^{6} \mathrm{t}, 73.19 \times 10^{6} \mathrm{t}$, and $75.06 \times 10^{6} \mathrm{t}$, respectively (Table 3), with the total carbon storage increasing by $9.9 \%$. Carbon storage services were mainly provided by farmland, grassland, and woodland. In terms of carbon storage per unit area of different land uses, grassland was the highest, followed by woodland and farmland.

Table 3. Carbon storage of different land use types in different periods $\left(10^{6} \mathrm{t}\right)$.

\begin{tabular}{cccccc}
\hline Land-Use Types & $\mathbf{2 0 0 0}$ & $\mathbf{2 0 0 5}$ & $\mathbf{2 0 1 0}$ & $\mathbf{2 0 1 5}$ & $\mathbf{2 0 1 8}$ \\
\hline Farmland & 33.12 & 33.63 & 43.19 & 43.00 & 42.02 \\
Woodland & 2.46 & 2.50 & 2.46 & 2.48 & 5.29 \\
Grassland & 32.71 & 31.75 & 27.63 & 27.71 & 27.75 \\
Water bodies & 0 & 0 & 0 & 0 & 0 \\
Construction land & 0 & 0 & 0 & 0 & 0 \\
Unused land & 0 & 0 & 0 & 0 & 0 \\
Total & 68.29 & 67.88 & 73.28 & 73.19 & 75.06 \\
\hline
\end{tabular}

The spatial variation of carbon storage in Ulansuhai Basin was small, where the highvalue area was concentrated in the Wula Mountain region in the eastern part of the basin, while the woodland was the most widely distributed, and carbon storage had a growing trend. The Ulanbuh Desert in the west of the basin had the weakest carbon storage capacity, while the Alaben Grassland in the east and the farmland in the central part had stronger carbon storage capacity (Figure 3). 

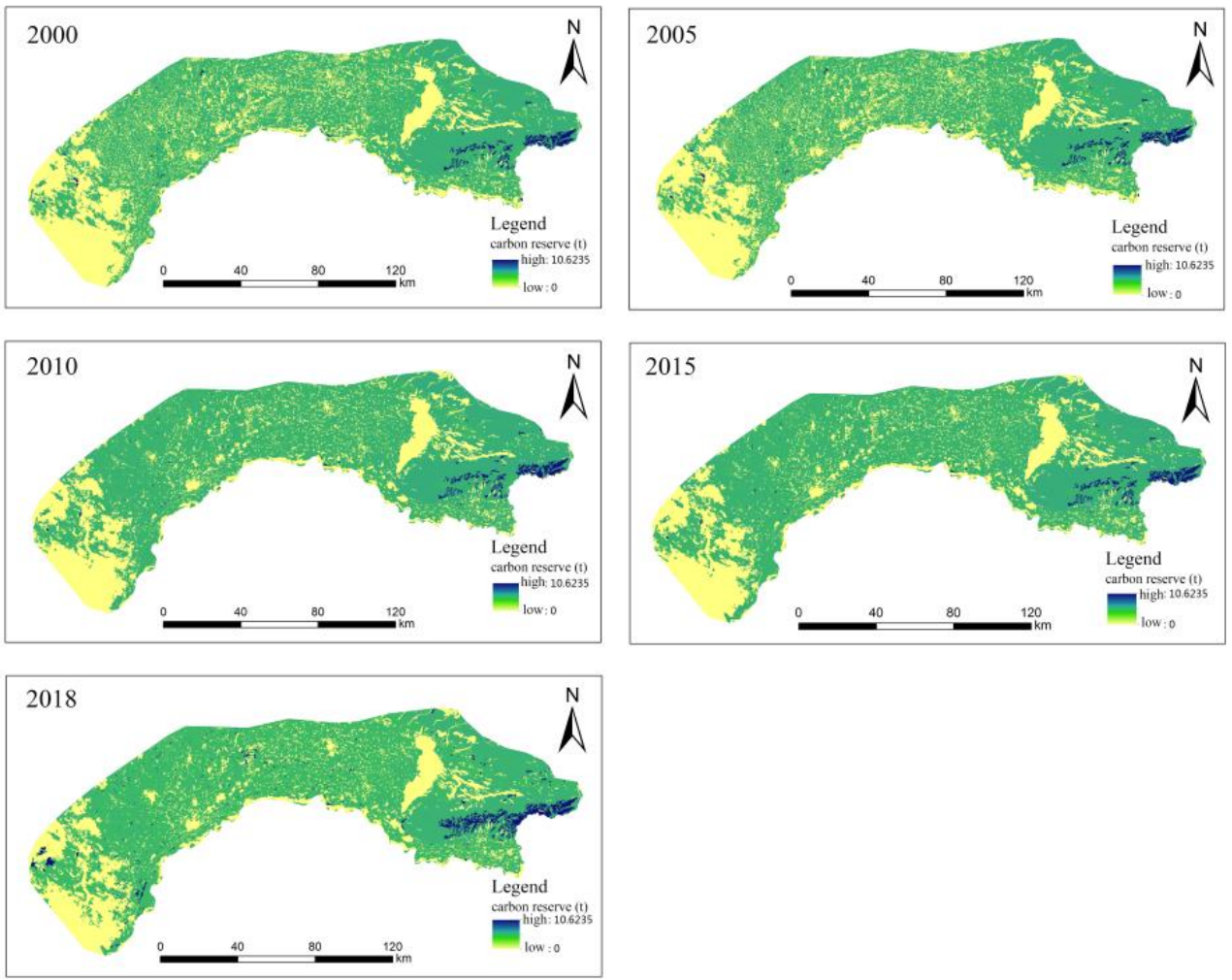

Figure 3. Spatial distribution of carbon storage in the study area from 2000 to 2018.

\subsubsection{Water Yield}

The total amounts of water yield in the five phases of Ulansuhai Basin from 2000 to 2018 were $17.41 \times 10^{6} \mathrm{~m}^{3}, 68.22 \times 10^{6} \mathrm{~m}^{3}, 118.29 \times 10^{6} \mathrm{~m}^{3}, 84.20 \times 10^{6} \mathrm{~m}^{3}$, and $250.05 \times 10^{6} \mathrm{~m}^{3}$, respectively (Table 4 ), with the total water yield increasing by $133.6 \%$.

Table 4. Water yield of different land-use types in different periods $\left(\mathrm{m}^{3}\right)$.

\begin{tabular}{cccccc}
\hline Land-Use Types & $\mathbf{2 0 0 0}$ & $\mathbf{2 0 0 5}$ & $\mathbf{2 0 1 0}$ & $\mathbf{2 0 1 5}$ & $\mathbf{2 0 1 8}$ \\
\hline Farmland & 7.20 & 9.20 & 13.56 & 10.23 & 17.21 \\
Woodland & 0.10 & 0.09 & 0.10 & 0.10 & 0.6 \\
Grassland & 4.27 & 4.88 & 6.88 & 5.06 & 10.85 \\
Water bodies & 0 & 0 & 0 & 0 & 0 \\
Construction land & 1.37 & 12.25 & 30.92 & 23.17 & 91.77 \\
Unused land & 4.47 & 41.80 & 66.83 & 45.64 & 129.62 \\
Total & 17.41 & 68.22 & 118.29 & 84.20 & 250.05 \\
\hline
\end{tabular}

Cultivated land, woodland, and grassland were the main land-use types in Ulansuhai Basin. Overall, the water production in Ulansuhai Basin showed a clear increasing trend. Among them, the water production of construction and unused land were relatively large, especially in 2018, when the numbers increased significantly-mainly due to the increase in land-use area and rainfall. They were followed by cultivated land, grassland, and woodland. Cultivated land was relatively large due to its large area. From the perspective of water production per unit area, except for construction land and unused land, the water production from lowest to highest was grassland, cultivated land, and woodland.

The overall trend in Ulansuhai Basin showed a gradually weakening trend from east to west (Figure 4). The high values were concentrated in the eastern part of the basin, mainly distributed around the Ulansuhai Lake area and the grassland and woodland areas, while the low values were in the middle and west of the basin. 

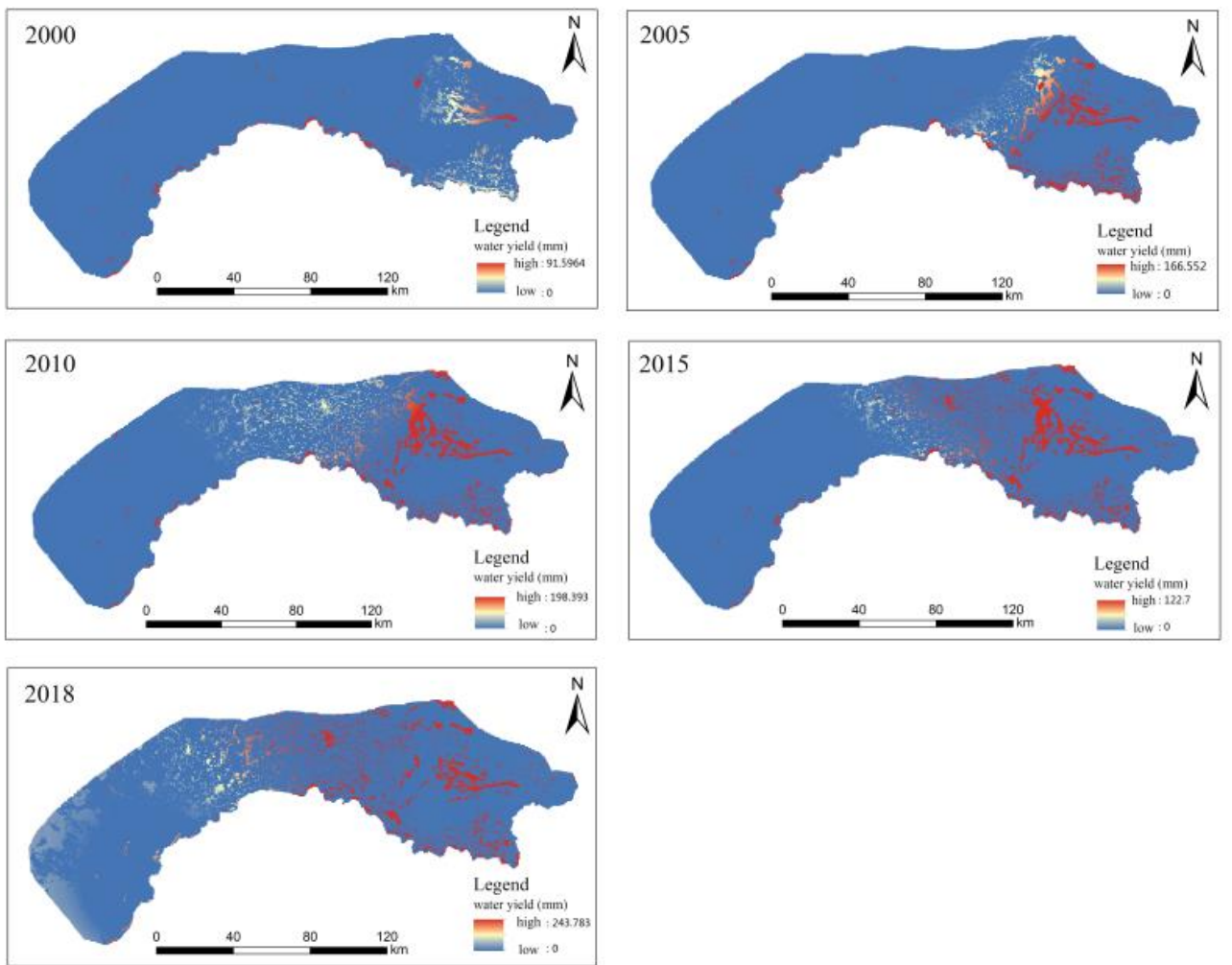

Figure 4. Spatial distribution of annual water yield in the study area from 2000 to 2018.

\subsubsection{Food Supply}

The total amounts of food supply in the five phases of Ulansuhai Basin from 2000 to 2018 were $2.13 \times 10^{6} t, 2.36 \times 10^{6} t, 3.24 \times 10^{6} t, 3.33 \times 10^{6} t$, and $5.04 \times 10^{6} t$, respectively (Table 5), with the total food supply increasing by $136.6 \%$.

Table 5. Food supply of different land use types in different periods $\left(10^{6} \mathrm{t}\right)$.

\begin{tabular}{cccccc}
\hline Land-Use Types & $\mathbf{2 0 0 0}$ & $\mathbf{2 0 0 5}$ & $\mathbf{2 0 1 0}$ & $\mathbf{2 0 1 5}$ & $\mathbf{2 0 1 8}$ \\
\hline Farmland & 2.01 & 1.82 & 2.66 & 2.36 & 3.96 \\
Grassland & 0.12 & 0.54 & 0.58 & 0.97 & 1.08 \\
Total & 2.13 & 2.36 & 3.24 & 3.33 & 5.04 \\
\hline
\end{tabular}

We only calculated cultivated land and grassland land uses, for which the food supply services were grain and grass, respectively. The high-value area was distributed in the central cultivated area, while the low-value area was distributed in the east and west of the basin (Figure 5). From the perspective of the unit area supply of the two types of land, there was an increasing trend year by year. 

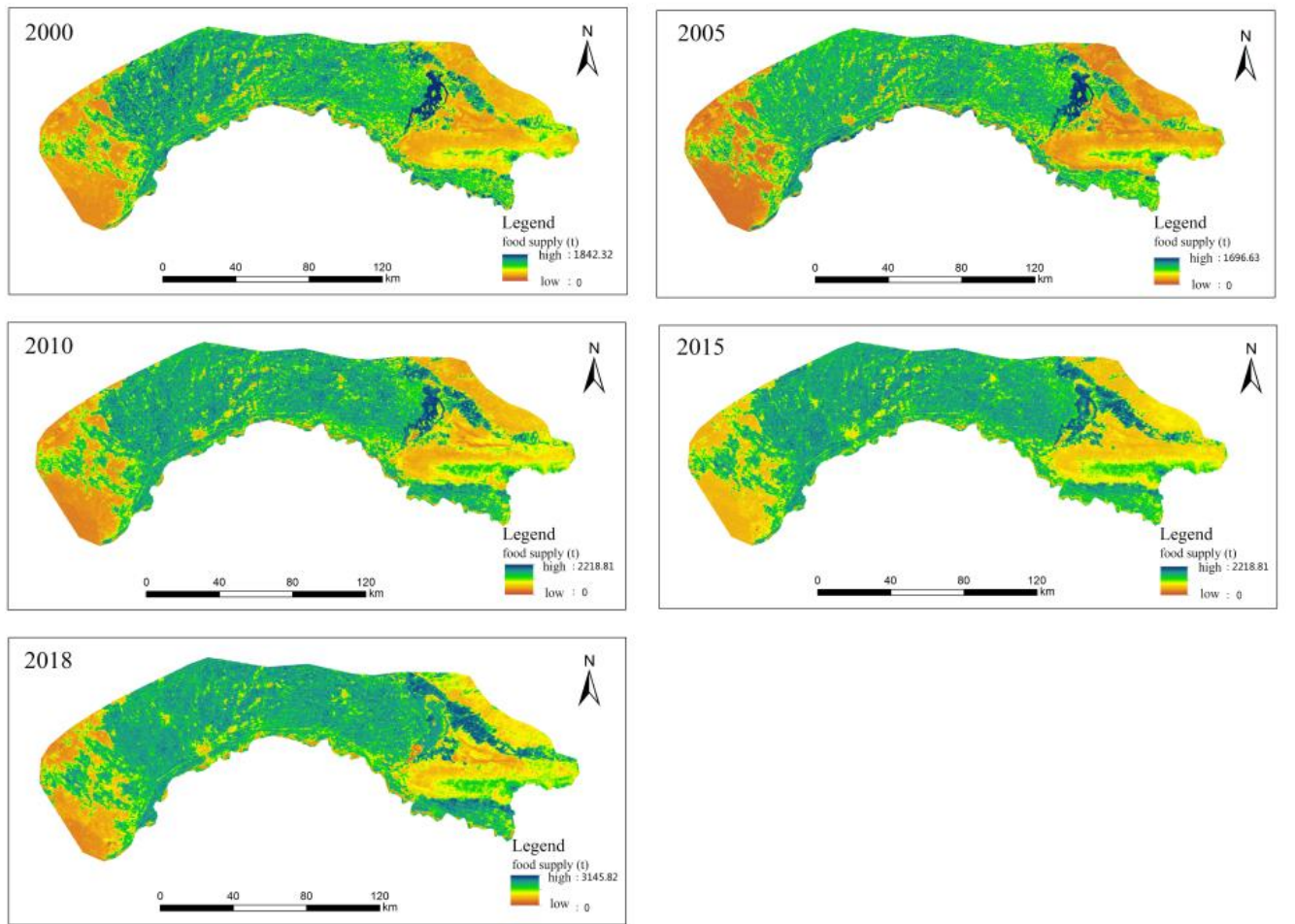

Figure 5. Spatial distribution of food supply in the study area from 2000 to 2018.

\subsubsection{Water Purification}

The total amounts of nitrogen output in the five phases of Ulansuhai Basin from 2000 to 2018 were $3481.40 \mathrm{t}, 3473.79 \mathrm{t}, 4470.94 \mathrm{t}, 4606.38 \mathrm{t}$, and $4375.84 \mathrm{t}$, respectively, while the total phosphorus outputs were $1046.87 \mathrm{t}, 1050.37 \mathrm{t}, 1440.62 \mathrm{t}, 1395.62 \mathrm{t}$, and $1395.63 \mathrm{t}$, respectively (Table 6). The total output of nitrogen and phosphorus increased by $25.7 \%$ and $33.3 \%$, respectively, from 2000 to 2018 . The output of nitrogen and phosphorus was mainly provided by farmland, construction land, and grassland. In terms of the water purification function of different land-use types, the highest nitrogen output per unit area was farmland, followed by construction land. Grassland possessed a better purification function.

Table 6. Nitrogen, phosphorus output of different land use types in different periods $\left(10^{3} \mathrm{~kg}\right)$.

\begin{tabular}{|c|c|c|c|c|c|c|}
\hline Land-Use Types & Element & 2000 & 2005 & 2010 & 2015 & 2018 \\
\hline Farmland & & 3141.50 & 3141.50 & 4216.11 & 4340.87 & 4086.62 \\
\hline Woodland & & 0.12 & 0.14 & 0.14 & 0.13 & 0.25 \\
\hline Grassland & & 4.80 & 4.74 & 4.34 & 4.11 & 4.24 \\
\hline Water bodies & Nitrogen & 0.02 & 0.01 & 0.01 & 0.02 & 0.02 \\
\hline $\begin{array}{c}\text { Construction } \\
\text { land }\end{array}$ & & 322.56 & 315.79 & 236.75 & 249.83 & 275.23 \\
\hline Unused land & & 12.40 & 11.61 & 13.59 & 11.42 & 9.48 \\
\hline Total & & 3481.40 & 3473.79 & 4470.94 & 4606.38 & 4375.84 \\
\hline Farmland & & 898.26 & 904.71 & 1330.91 & 1371.04 & 1268.81 \\
\hline Woodland & & 0.04 & 0.05 & 0.05 & 0.04 & 0.08 \\
\hline Grassland & & 2.16 & 2.13 & 1.95 & 1.84 & 1.91 \\
\hline Water bodies & Phosphorus & 0.02 & 0.01 & 0.01 & 0.02 & 0.02 \\
\hline $\begin{array}{c}\text { Construction } \\
\text { land }\end{array}$ & & 145.15 & 142.11 & 106.54 & 112.42 & 123.85 \\
\hline Unused land & & 1.24 & 1.36 & 1.16 & 1.14 & 0.95 \\
\hline Total & & 1046.87 & 1050.37 & 1440.62 & 1486.50 & 1395.62 \\
\hline
\end{tabular}


The high-value area of nitrogen and phosphorus output were mainly concentrated in the center of the study area, while the low-value areas were concentrated in the west and part of the northeast area (Figures 6 and 7).
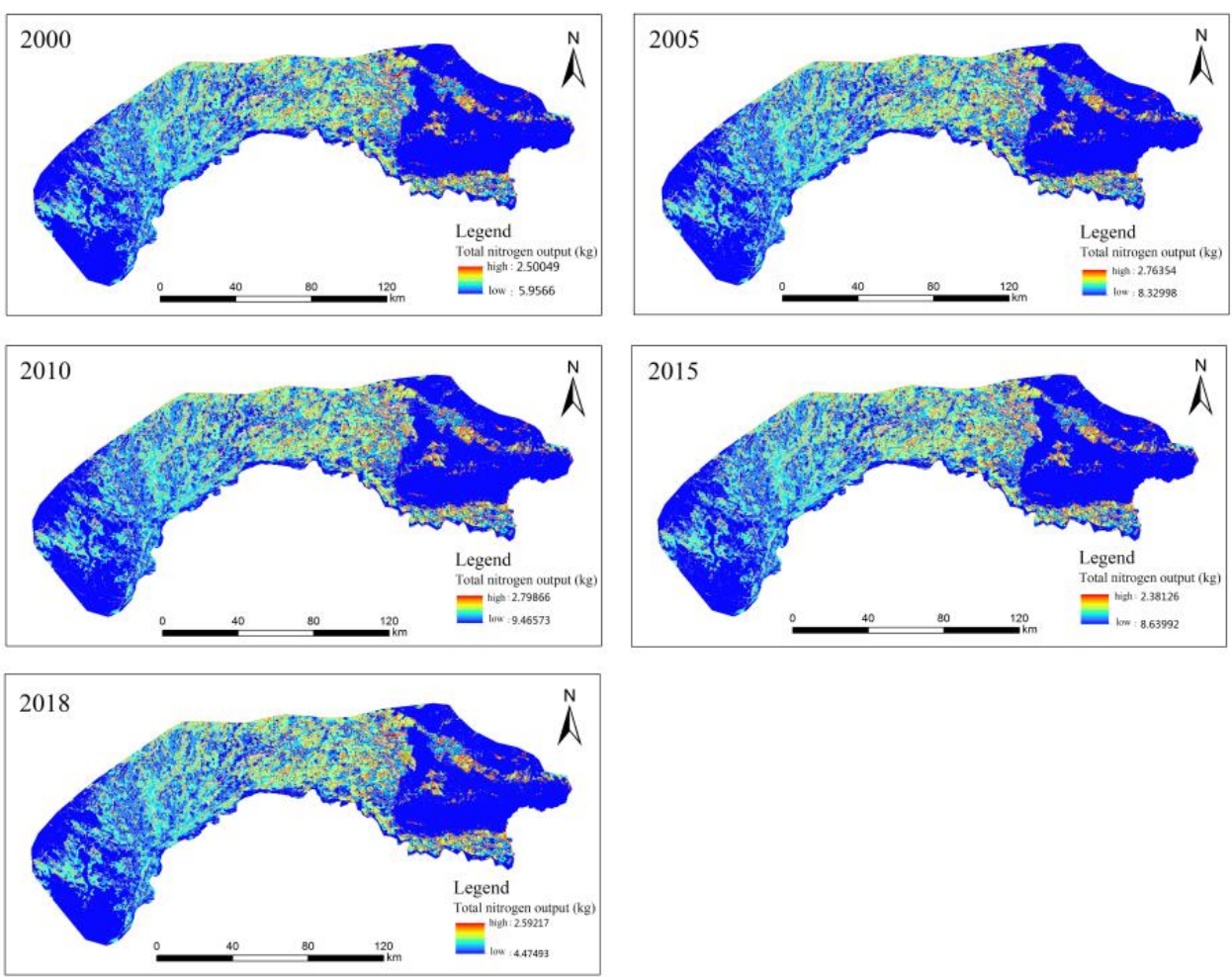

Figure 6. Spatial distribution of nitrogen and phosphorus output in the study area from 2000 to 2018.
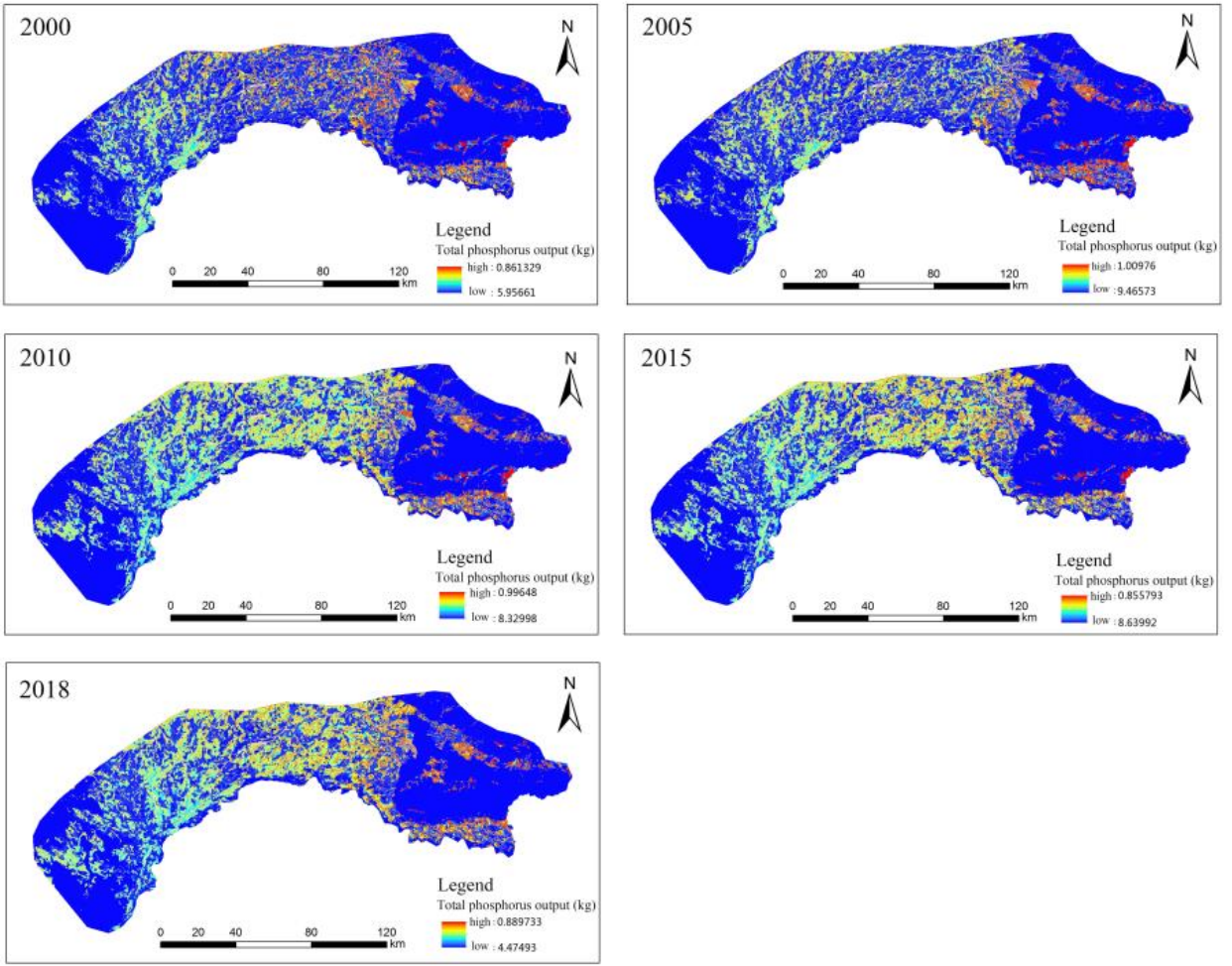

Figure 7. Spatial distribution of nitrogen and phosphorus output in the study area from 2000 to 2018. 


\subsection{Trade-Offs of Ecosystem Services in Ulansuhai Basin}

The interactions between various ecosystem services in Ulansuhai Basin were different, and the trade-offs and synergistic relationships have changed over time. Trade-offs, synergistic, and neutral relationships existed in 10 groups among five functions in five periods of time-namely three pairs, two pairs, and five pairs in 2000; five pairs, three pairs, and two pairs in 2005; four pairs, four pairs, and two pairs in 2010; five pairs, four pairs, and one pair in 2015; and five pairs, four pairs, and one pair in 2018, respectively (Table 7).

Table 7. Correlation of ecosystem services in the study area from 2000 to 2018.

\begin{tabular}{|c|c|c|c|c|c|}
\hline Category & SC & CS & WP & FS & WY \\
\hline \multicolumn{6}{|c|}{2000} \\
\hline SC & 1.000 & & & & \\
\hline CS & $0.218^{* *}$ & 1.000 & & & \\
\hline WP & 0.03 & $-0.210^{* *}$ & 1.000 & & \\
\hline FS & $-0.146^{* *}$ & $0.291^{* *}$ & $-0.438^{* *}$ & 1.000 & \\
\hline WY & -0.021 & -0.023 & -0.012 & 0.034 & 1.000 \\
\hline \multicolumn{6}{|c|}{2005} \\
\hline SC & 1.000 & & & & \\
\hline CS & $0.217 * *$ & 1.000 & & & \\
\hline WP & 0.025 & $-0.215^{* *}$ & 1.000 & & \\
\hline FS & $-0.123^{* *}$ & $0.315^{* *}$ & $-0.416^{* *}$ & 1.000 & \\
\hline WY & -0.016 & $-0.236^{* *}$ & 0.049 * & $-0.047 *$ & 1.000 \\
\hline \multicolumn{6}{|c|}{2010} \\
\hline SC & 1.000 & & & & \\
\hline CS & $0.190 * *$ & 1.000 & & & \\
\hline WP & $0.039 *$ & $-0.260^{* *}$ & 1.000 & & \\
\hline FS & $-0.115^{* *}$ & $0.323^{* *}$ & $-0.459^{* *}$ & 1.000 & \\
\hline WY & -0.001 & $-0.361^{* *}$ & $0.091^{* *}$ & -0.034 & 1.000 \\
\hline \multicolumn{6}{|c|}{2015} \\
\hline SC & 1.000 & & & & \\
\hline CS & $0.204^{* *}$ & 1.000 & & & \\
\hline WP & $0.074^{* *}$ & $-0.261^{* *}$ & 1.000 & & \\
\hline FS & $-0.110 * *$ & $0.343^{* *}$ & $-0.472 * *$ & 1.000 & \\
\hline WY & $-0.041 *$ & $-0.368^{* *}$ & $0.100^{* *}$ & -0.037 & 1.000 \\
\hline \multicolumn{6}{|c|}{2018} \\
\hline SC & 1.000 & & & & \\
\hline $\mathrm{CS}$ & $0.253 * *$ & 1.000 & & & \\
\hline WP & $0.146^{* *}$ & $-0.193 * *$ & 1.000 & & \\
\hline FS & $-0.147^{* *}$ & $0.383^{* *}$ & $-0.467^{* *}$ & 1.000 & \\
\hline WY & -0.03 & $-0.469^{* *}$ & $0.077^{* *}$ & $-0.133^{* *}$ & 1.000 \\
\hline
\end{tabular}

Note. ${ }^{*}$ At a level of 0.05 (two-tailed), the correlation is significant; ${ }^{* *}$ at a level of 0.01 (two-tailed), the correlation is significant. WY, FS, WP, CS, and SC represent water production, food supply, water purification, carbon storage, and soil conservation, respectively. In the assessment of ecosystem services, the output of nitrogen and phosphorus was used to reflect the ability of water purification. The greater the output of nitrogen and phosphorus, the weaker the water purification capacity, and vice versa.

The trade-offs relationships changed greatly between 2000 and 2018. These relationships, ranked from strongest to weakest, in 2000 were food supply-water purification, water purification-carbon storage, and food supply-soil conservation. Those in 2015 were food supply-water purification, water yield-carbon storage, water purification-carbon storage, food supply-soil conservation, and water yield-food supply. In 2010, the ranking was food supply-water purification, water production-carbon storage, water purification-carbon storage, and food supply-soil conservation. In 2015, the ranking was food supply-water purification, water production-carbon storage, water purification-carbon storage, food supply-soil conservation, and water production-soil conservation. In 2018, the ranking was water production-carbon storage, food supply-water purification, water purificationcarbon storage, food supply-soil conservation, and water production-food supply.

The synergies between 2000 and 2018 also changed. These relationships, ranked from strongest to weakest, in 2000 were food supply-carbon storage and soil conservation- 
carbon storage. The ranking in 2005 was food supply-carbon storage, carbon storagesoil conservation, and water production-water purification. In 2010, the ranking was food supply-carbon storage, carbon storage-soil conservation, water production-water purification, and water purification-soil conservation. In 2015, the ranking was food supplycarbon storage, carbon storage-soil conservation, water production-water purification, and water quality purification-soil conservation. In 2018, the ranking was food supply-carbon storage, carbon storage-soil conservation, water purification-soil conservation, and water production-water purification. The remaining pairs of functions were irrelevant-that is, they were neutral relationships.

From the above analysis, it can be seen that relationships of food supply-water purification, food supply-soil conservation, and water purification-carbon storage were negative from 2000 to 2018, and the trade-offs relationship between water production and carbon storage changed significantly. The relationships of food supply-carbon storage and carbon storage-soil maintenance were positive, and the synergistic relationships of water purification-soil maintenance and water production-water purification strengthened over time. Overall, trade-offs relationships were the main relationships among the five services in Ulansuhai Basin.

\subsection{Trade-Offs of Ecosystem Services in Different Functional Zones}

According to the current land-use types and corresponding functions, the study area can be divided into five functional zones [30]: I, the Alaben Grassland Soil and Water Conservation and Vegetation Restoration Zone; II, the Hetao Irrigation District Water System Ecological Protection Zone; III, the UlansuHai Ecological Protection Zone; IV, the Wula Mountain Water Conservation and Geological Environmental Management Zone; and V, the Ulan Buhe Desert Comprehensive Management Zone (Figure 8, Table 8).

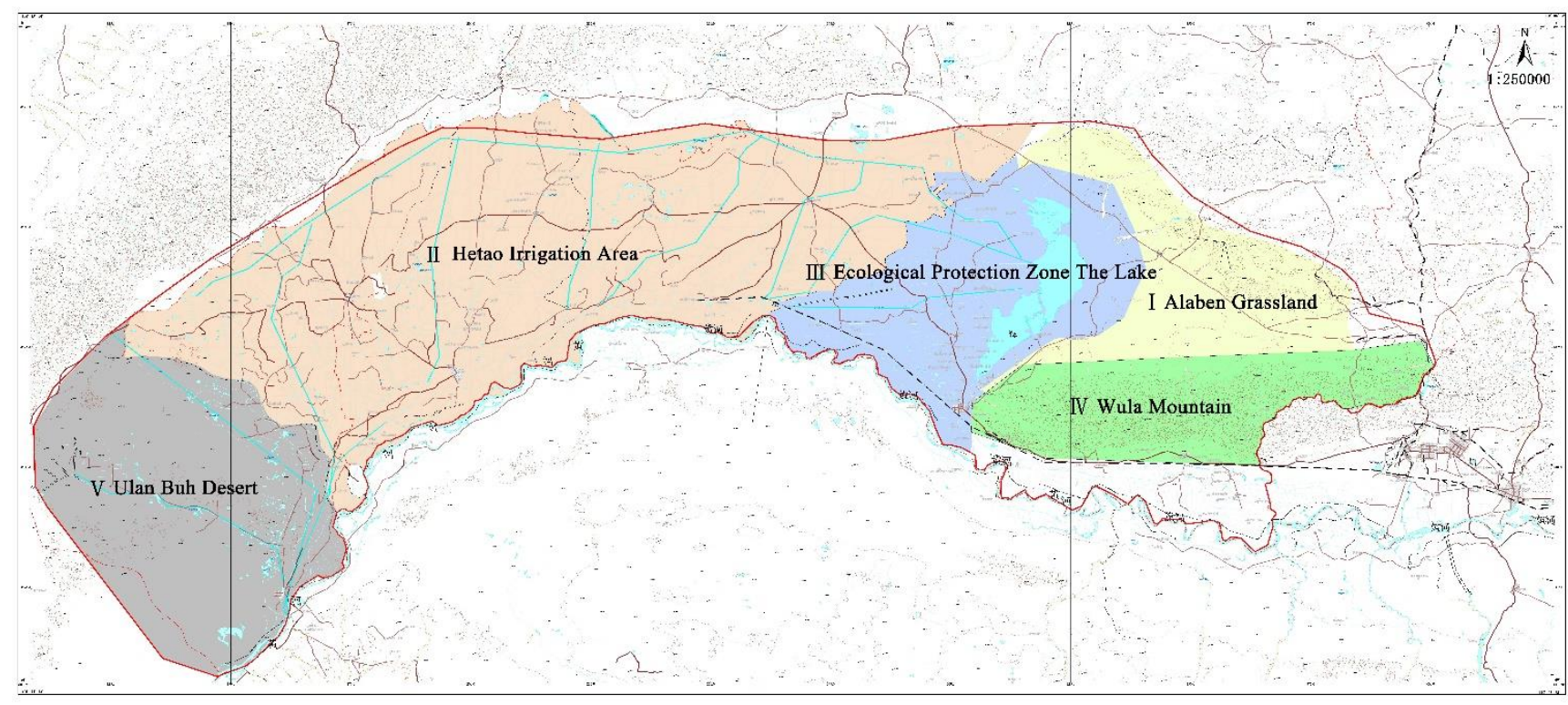

legend

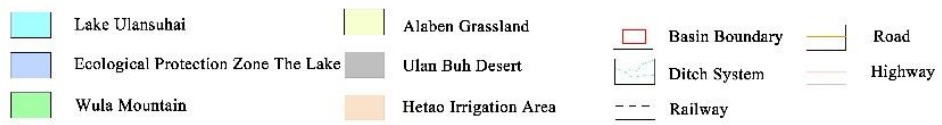

Figure 8. Functional restoration zoning map of Ulansuhai Basin. 
Table 8. Trade-offs and synergistic relationships of functional areas in 2018.

\begin{tabular}{|c|c|c|c|c|c|}
\hline Category & WY & FS & WP & $\mathrm{CS}$ & $\mathrm{SC}$ \\
\hline \multicolumn{6}{|c|}{ I } \\
\hline WY & 1.000 & & & & \\
\hline FS & 0.073 & 1.000 & & & \\
\hline WP & $-0.364^{* *}$ & $-0.162^{* *}$ & 1.000 & & \\
\hline CS & $-0.513^{* *}$ & $-0.148^{* *}$ & $0.464^{* *}$ & 1.000 & \\
\hline SC & -0.035 & $-0.253^{* *}$ & -0.055 & $0.193^{* *}$ & 1.000 \\
\hline \multicolumn{6}{|c|}{ II } \\
\hline WY & 1.000 & & & & \\
\hline FS & $-0.093 *$ & 1.000 & & & \\
\hline WP & $-0.224^{* *}$ & $-0.257^{* *}$ & 1.000 & & \\
\hline CS & $-0.266^{* *}$ & $0.145^{* *}$ & $0.141^{* *}$ & 1.000 & \\
\hline SC & -0.01 & $-0.092 *$ & 0.025 & -0.032 & 1.000 \\
\hline \multicolumn{6}{|c|}{ III } \\
\hline WY & 1.000 & & & & \\
\hline FS & 0.042 & 1.000 & & & \\
\hline WP & $-0.452 * *$ & $-0.252^{* *}$ & 1.000 & & \\
\hline CS & $0.130 * *$ & 0.045 & $-0.152^{* *}$ & 1.000 & \\
\hline SC & $0.112 *$ & -0.079 & -0.027 & $0.118^{* *}$ & 1.000 \\
\hline \multicolumn{6}{|c|}{ IV } \\
\hline WY & 1.000 & & & & \\
\hline FS & $0.427^{* *}$ & 1.000 & & & \\
\hline WP & $-0.581^{* *}$ & $-0.294^{* *}$ & 1.000 & & \\
\hline CS & $-0.495 * *$ & $-0.304^{* *}$ & $0.477^{* *}$ & 1.000 & \\
\hline SC & $-0.292 * *$ & $-0.310^{* *}$ & $0.186^{* *}$ & $0.587^{* *}$ & 1.000 \\
\hline \multicolumn{6}{|c|}{ V } \\
\hline WY & 1.000 & & & & \\
\hline FS & $-0.341^{* *}$ & 1.000 & & & \\
\hline WP & $-0.117^{* *}$ & $-0.384^{* *}$ & 1.000 & & \\
\hline CS & $-0.167^{* *}$ & $0.657^{* *}$ & $-0.196^{* *}$ & 1.000 & \\
\hline SC & $0.088 *$ & $-0.176^{* *}$ & $0.114^{* *}$ & $-0.169^{* *}$ & 1.000 \\
\hline
\end{tabular}

Note. ${ }^{*}$, At level 0.05 (two-tailed), the correlation is significant; ${ }^{* *}$ at level 0.01 (two-tailed), the correlation is significant. Among them, WY, FS, WP, CS, SC represent water production, food supply, water purification, carbon storage, and soil conservation, respectively. In the assessment of ecosystem services, the output of nitrogen and phosphorus was used to reflect the ability of water purification. The greater the output of nitrogen and phosphorus, the weaker the water purification capacity, and vice versa.

In zone I, the relationships of carbon storage-water purification and soil conservationcarbon storage were all synergistic, where the correlation between carbon storage and water purification was stronger. The relationships of water purification-water production, carbon storage-water production, soil conservation-food supply, water purification-food supply, and carbon storage-food supply were trade-offs, where the relationship of carbon storage-water production was relatively stronger than others.

In zone II, the relationships of carbon storage-food supply and carbon storage-water purification were synergistic, where the relationship of carbon storage-food supply was stronger. The relationships of carbon storage-water production, water purification-food supply, water purification-water production, food supply-water production, and soil conservation-food supply were trade-offs, where the carbon storage-water production relationship was relatively stronger than others.

In zone III, the relationships of carbon storage-water production, soil conservationcarbon storage, and soil conservation-water production were synergistic, where the relationship between carbon storage and water production was stronger. The relationships of water purification-water production, water purification-food supply, and carbon storagewater purification were trade-offs, among which the water production-water purification relationship was relatively stronger than others.

In zone IV, there were synergistic relationships in soil conservation-carbon storage, carbon storage-water purification, food supply-water production, and soil conservationwater purification. The carbon storage-water purification and carbon storage-soil con- 
servation relationships were relatively stronger. The relationships of water purificationwater production, carbon storage-water production, soil conservation-food supply, carbon storage-food supply, water purification-food supply, and soil conservation-water production were trade-offs, of which the carbon storage-water purification and carbon storage-water production relationships were relatively stronger.

In zone $\mathrm{V}$, there were synergistic relationships between carbon storage-food supply, soil conservation-water purification, and soil conservation-water production, where the relationship between food supply and carbon storage was relatively stronger. The relationships of water purification-food supply, food supply-water production, carbon storage-water purification, soil conservation-carbon storage, carbon storage-water production, and water purification-water production were trade-offs, where the relationships of water purification-food supply and food supply-water production were relatively stronger.

Water purification-water production and food supply-water purification showed a trade-offs relationship in all functional zones.

Food supply-carbon storage had a synergistic relationship but showed a trade-offs relationship in zones I and IV. Carbon storage-soil conservation was mainly a synergistic relationship, but was a trade-offs relationship in zone V. Water production-carbon storage was generally a trade-offs relationship, but it was a synergistic relationship in zone III. Water purification-carbon storage was generally a synergistic relationship, but it showed a trade-offs relationship in zones III and V. The relationship of water production-food supply was mainly synergistic, but was a trade-offs relationship in zones II and V. Water production-soil maintenance mainly showed a synergistic relationship, with a trade-offs relationship in zone IV and a neutral relationship in zone I and II.

The results show that there was spatial heterogeneity among different ecosystem services in Ulansuhai Basin. There were stable and changeable trade-offs and synergistic relationships between different functional areas.

\section{Discussion}

The changes of ecosystem services are mainly affected by climate change and human activities. The spatial and temporal changes of ecosystem services in Ulansuhai basin were mainly the result of land use change, precipitation, temperature, and human activities [45-47]. It can be concluded from the result that the increase in ecosystem services in Ulansuhai basin were mainly due to the change in land use. The central part was farmland irrigation area, a high food supply service value area; at the same time, it was also a relatively weak area in terms of water purification capacity. The use of agricultural fertilizer, pesticide, and agricultural membranes have increased the concentrations of nitrogen and phosphorus in soil. The land-use types were mainly water, woodland, and grassland in the eastern part, and the values of soil conservation, carbon storage, and water yield were high in this area. For example, the high value areas of soil conservation and carbon reserves were mainly distributed in the woodland and grassland at the east of the basin. The vegetation coverage of woodland and grassland areas were relatively high, with strong rainfall interception capability, which plays a critical role in soil maintenance. Climate change is also a driving factor that affects ecosystem services. Studies have shown that among the impacts of precipitation, management policies, terrain, and soil erodibility on soil conservation and water production, the impact of precipitation was greater $[6,23]$. The management policies related to human activities had relatively little impact on those services, and terrain had a greater impact on soil conservation. Generally, the land with slopes performed better in soil conservation. Moreover, vegetation coverage is also an important factor to be considered [48].

Ecosystem services had a certain spatial scale effect, and the interaction between services may lead to changes in the trade-offs and synergistic relationship. There was a trend of decreasing coordination and strengthened trade-offs relationships at the overall scale of the Ulansuhai Basin. On the specific small scale of the functional area, there were different trade-offs and collaborative relationships. In zones I, II, IV, and V, the trade-offs relationship 
was the dominant relationship, while the synergistic relationship was weakened. In zone III, the synergistic relationship was the dominant one and the trade-offs relationship was weakened. The main reason for this was that the land types of Ulansuhai Basin were various, including plains, mountains, hills, and so on, and there were interferences and constraints between different types of ecosystems, thus forming a complex balance and coordinate relationship between various services of the ecosystem. Farmland, with strong food supply capacity, had a higher demand for irrigation and improper cultivation; such factors lead to soil erosion, cause the salt and alkali to become exposed in the surface, and decrease the soil conservation capacity of the ecosystem. The relationship between soil conservation and food supply was a trade-offs $[19,45]$. Furthermore, the roots of trees have a positive effect in stabilizing slopes, reducing soil erosion, and conserving soil and water. Forestation can increase carbon storage, enhance the ability of carbon fixation and oxygen release, and promote climate regulation. At the same time, it plays a certain role in conserving soil and water to resist soil erosion, thus improving the regulation and supporting ecosystem services [46,47]. The increase in farmland area can improve the grain yield, but it would reduce carbon fixation and vegetation coverage $[17,48]$. Therefore, in every functional area, the main relationships between services and the functional relationships among functional areas were close. The phenomenon of this relationship was mainly caused by the difference of land-use types and the difference of human use patterns caused by it.

As an important food base and a typical agricultural basin in an arid area in northern China, the role of Ulansuhai Basin was mainly focused on supplying food products, ensuring the quantity and quality of Ulansuhai, and maintaining the ecological environmental safety of the basin. Agriculture is the foundation, water resources are the lifeblood, and forest and grass are the ecological safeguard. Therefore, we need to do a good job in mountain-river-forest-farmland-lake-grasslands restoration projects and system management, thus maintaining the sustainable development of ecology, society, and economy.

In general, basin management primarily involves the systematic management of water resources. Especially for an agricultural basin in an arid area, the dynamic balance of water quantity in the basin is the primary consideration for integrated water resources management. Insufficient water affects the guarantee of agricultural water consumption and watershed ecological water consumption, as well as the balance between agricultural water consumption and watershed ecological water consumption, which ultimately leads to the imbalance of the basin's hydrological process. Therefore, water resource management in this basin should adopt the following strategies. First, the regulation and storage function of Lake Ulansuhai on water resources in the basin should be highly valued. Expanding storage capacity and supplying water reasonably are effective measures to enhance the regulatory function of Lake Ulansuhai. Second, it is very important to ensure the rational allocation and utilization of water resources in the basin [49], strengthen unified scheduling, and implement hierarchical management.

Therefore, in view of the different ecological function zones in the Ulansuhai Basin, we propose specific ecological protection measures, mainly including the following five aspects. (1) The ecological Protection Zone around Lake Ulansuhai: Aiming at the problem of nonpoint source and point source pollution, the functions of pollution control and emissions reduction in the lake-surrounding ecological protection zone can play an important role in improving the water quality of Lake Ulansuhai. (2) The ecological protection network of the ditch system of Hetao irrigation area: Through engineering measures and vegetation buffer construction, the water conveyance function of the ditch and water quality can be guaranteed and improved. (3) In the area of Lake Ulansuhai, returning farmland and grassland to lake appropriately can increase the storage capacity and water quantity of Lake Ulansuhai and enhance its regulation function. At the same time, lake internal pollutionsource control projects should be carried out in order to improve water quality. (4) The water conservation and vegetation restoration area of Alaben grassland and Wula Mountain should be important focuses of ecological protection. In these two areas, management 
measures should aim at improving the structure and function of vegetation, preventing soil erosion, and reducing pollutants and sediment entering the lake. (5) In the comprehensive treatment area of Ulanbuh Desert, the prevention and control of desertification through vegetation restoration measures should be the main task of ecological conservation.

\section{Conclusions}

There were obvious temporal and spatial differences in various ecosystem services in the Ulansuhai Basin. The results of the study show that, from 2000 to 2018, different ecosystem services in the Ulansuhai Basin experienced a significant increase as a whole, and the ecosystem service functions were degraded in some areas (i.e., water purification functions). The main spatial pattern was soil conservation, carbon storage, and water production being high in the east and low in the central and western regions, while water purification and food supply were high in the central and low in the east and west. Changes in ecosystem service patterns were mainly caused by regional differences, due to different types of land use.

The trade-offs and synergies between various ecosystem services in the Ulansuhai Basin also showed obvious spatial heterogeneity. The research results indicate that there were trade-offs, synergies, and neutral relationships among the five functions of soil conservation, carbon storage, water production, food supply, and water purification. The main relationship was trade-offs, and it tended to be strengthened markedly, while synergy tended to be strengthened slightly. In different functional areas, the trade-offs and synergy between ecosystem services had changed, to varying degrees. Therefore, the rational allocation of the interaction between ecosystem services is particularly important for coordinating the harmonious development of ecology, environment, and resources.

Author Contributions: Conceptualization, G.W., X.F. and L.W.; methodology, X.F.; software, S.L.; validation, L.W., S.L. and E.Y.; formal analysis, L.W.; investigation, S.L.; resources, E.Y.; data curation, L.W.; writing—original draft preparation, L.W.; writing—review and editing, L.W., E.Y. and S.L.; visualization, E.Y.; supervision, S.L.; project administration, G.W. All authors have read and agreed to the published version of the manuscript.

Funding: This research was funded by The National Key Research and Development Program of China (No. 2016YFC0503603).

Institutional Review Board Statement: Not applicable.

Informed Consent Statement: Not applicable.

Data Availability Statement: The data presented in this study are available within the article.

Acknowledgments: The authors thank the two anonymous reviewers for their valuable suggestions.

Conflicts of Interest: The authors declare no conflict of interest.

\section{References}

1. Costanza, R.; d’Arge, R.; de Groot, R.; Farber, S.; Grasso, M.; Hannon, B.; Limburg, K.; Naeem, S.; O’Neill, R.V.; Paruelo, J.; et al. The value of the world's ecosystem services and natural capital. Nature 1997, 387, 253-260. [CrossRef]

2. Pearce, D. Ecological accountancy. Science 1997, 277, 1783. [CrossRef]

3. Fu, B.; Zhou, G.; Bai, Y.; Song, C.; Liu, J.; Zhang, H.; Lv, Y.; Zheng, H.; Xie, G. The main terrestrial ecosystem services and ecological security in china. Adv. Earth Sci. 2009, 24, 571-576.

4. Abernethy, V.D. Nature's services: Societal dependence on natural ecosystems. Popul. Environ. 1999, 20, 277-278. [CrossRef]

5. Lin, J.; Huang, J.; Prell, C.; Bryan, B.A. Changes in supply and demand mediate the effects of land-use change on freshwater ecosystem services flows. Sci. Total Environ. 2021, 763, 143012. [CrossRef] [PubMed]

6. De Simone, W.; Iannella, M.; D'Alessandro, P.; Biondi, M. Assessing influence in biofuel production and ecosystem services when environmental changes affect plant-pest relationships. GCB Bioenergy 2020, 12, 864-877. [CrossRef]

7. Howe, C.; Suich, H.; Vira, B.; Mace, G.M. Creating win-wins from trade-offs? Ecosystem services for human well-being: A meta-analysis of ecosystem service trade-offs and synergies in the real world. Glob. Environ. Chang. 2014, 28, 263-275. [CrossRef]

8. Ainscough, J.; de Vries Lentsch, A.; Metzger, M.; Rounsevell, M.; Schröter, M.; Delbaere, B.; de Groot, R.; Staes, J. Navigating pluralism: Understanding perceptions of the ecosystem services concept. Ecosyst. Serv. 2019, 36, 100892. [CrossRef] 
9. Izquierdo, A.E.; Clark, M.L. Spatial analysis of conservation priorities based on ecosystem services in the atlantic forest region of misiones, argentina. Forests 2012, 3, 764-786. [CrossRef]

10. Li, S.; Zhang, C.; Liu, J.; Zhun, W.; Ma, C.; Wang, Y. Ecosystem service trade-offs and synergy research progress and geography research topics. Geogr. Res. 2013, 32, 1379-1390.

11. Dai, E.; Wang, X.; Zhu, J.; Zhao, D. Methods, tools and research framework of ecosystem service trade-offs. Geogr. Res. 2016, 35, 1005-1016.

12. Bennett, E.M.; Peterson, G.D.; Gordon, L.J. Understanding relationships among multiple ecosystem services. Ecol. Lett. 2009, 12, 1394-1404. [CrossRef] [PubMed]

13. Boyd, J.; Banzhaf, S. What are ecosystem services? The need for standardized environmental accounting units. Ecol. Econ. 2007, 63, 616-626. [CrossRef]

14. Bekele, E.G.; Nicklow, J.W. Multiobjective management of ecosystem services by integrative watershed modeling and evolutionary algorithms. Water Resour. Res. 2005, 41. [CrossRef]

15. Willemen, L.; Veldkamp, A.; Verburg, P.H.; Hein, L.; Leemans, R. A multi-scale modelling approach for analysing landscape service dynamics. J. Environ. Manag. 2012, 100, 86-95. [CrossRef]

16. Nelson, E.; Mendoza, G.; Regetz, J.; Polasky, S.; Tallis, H.; Cameron, D.; Chan, K.M.A.; Daily, G.C.; Goldstein, J.; Kareiva, P.M.; et al. Modeling multiple ecosystem services, biodiversity conservation, commodity production, and tradeoffs at landscape scales. Front. Ecol. Environ. 2009, 7, 4-11. [CrossRef]

17. Turner, K.G.; Odgaard, M.V.; Bøcher, P.K.; Dalgaard, T.; Svenning, J.-C. Bundling ecosystem services in denmark: Trade-offs and synergies in a cultural landscape. Landsc. Urban Plan. 2014, 125, 89-104. [CrossRef]

18. Cademus, R.; Escobedo, F.J.; McLaughlin, D.; Abd-Elrahman, A. Analyzing trade-offs, synergies, and drivers among timber production, carbon sequestration, and water yield in pinus elliotii forests in southeastern USA. Forests 2014, 5, $1409-1431$. [CrossRef]

19. Qin, K.; Li, J.; Yang, X. Trade-off and synergy among ecosystem services in the guanzhong-tianshui economic region of china. Int. J. Environ. Res. Public Health 2015, 12, 14094-14113. [CrossRef]

20. Fu, B.; Yu, D. Trade-off analyses and synthetic integrated method of multiple ecosystem services. Resour. Sci. 2016, 38, 1-9.

21. Tolessa, T.; Senbeta, F.; Kidane, M. The impact of land use/land cover change on ecosystem services in the central highlands of ethiopia. Ecosyst. Serv. 2017, 23, 47-54. [CrossRef]

22. Li, R.; Zheng, H.; O'Connor, P.; Xu, H.; Li, Y.; Lu, F.; Robinson, B.E.; Ouyang, Z.; Hai, Y.; Daily, G.C. Time and space catch up with restoration programs that ignore ecosystem service trade-offs. Sci. Adv. 2021, 7, eabf8650. [CrossRef] [PubMed]

23. Heterogeneity and regional differences in ecosystem services responses driven by the "three modernizations". Land Degrad. Dev. 2021, 32, 3743-3761. [CrossRef]

24. Kindu, M.; Schneider, T.; Teketay, D.; Knoke, T. Changes of ecosystem service values in response to land use/land cover dynamics in munessa-shashemene landscape of the ethiopian highlands. Sci. Total Environ. 2016, 547, 137-147. [CrossRef] [PubMed]

25. Li, Z. Research on the Spatial Trade-Off and Coordination of Ecosystem Services in Arid Inland River Basin-A Case Study of Jiajiu Region. Master's Thesis, Northwest Normal University, Lanzhou, China, 2017.

26. Zhao, Y.; Jiang, C.; Dong, X.; Yang, Z.; Wen, M.; Yang, J. Understanding the complex environmental management through a len of food-water-ecosystem nexus: Insights from an ecosystem restoration hotspot in dryland. Sci. Total Environ. 2021, 783, 147029. [CrossRef] [PubMed]

27. Guo, L. Constructing the endogenous mechanism of ecological protection and restoration of "mountains, water, forests, fields, lakes and grass". China Resour. Compr. Util. 2019, 37, 133-135.

28. Shi, C.; Pan, Y. Impact of waterfowl nature reserve on ecological environment in wuliangsuhai wetland, inner mongolia. Inn. Mong. Environ. Sci. 2017, 29, 171-172.

29. Shi, J. The necessity of wuliangsuhai wetland restoration. Inn. Mong. For. Investig. Des. 2018, 41, 56-80.

30. Tian, Y.; Feng, Q.; Tang, M.; Zheng, S.; Liu, C.; Wu, D.; Wang, L. Ecological protection and restoration of forest, wetland, grassland and cropland based on the perspective of ecosystem assessment: A case study in wuliangsuhai watershed. Acta Ecol. Sin. 2019, $39,8826-8836$.

31. Tang, Y.; Zhu, W.; Zhang, H.; Song, Y. A review on principle and application of the invest model. Ecol. Sci. 2015, 34, $204-208$.

32. Wu, Y.; Zhang, X.; Li, C.; Xu, Y.; Hao, F.; Yin, G. Ecosystem service trade-offs and synergies under influence of climate and land cover change in an afforested semiarid basin, China. Ecol. Eng. 2021, 159, 106083. [CrossRef]

33. Ran, C.; Wang, S.; Bai, X.; Tan, Q.; Zhao, C.; Luo, X.; Chen, H.; Xi, H. Trade-offs and synergies of ecosystem services in southwestern China. Environ. Eng. Sci. 2020, 37, 669-678. [CrossRef]

34. Ma, X.; Zhu, J.; Zhang, H.; Yan, W.; Zhao, C. Trade-offs and synergies in ecosystem service values of inland lake wetlands in central asia under land use/cover change: A case study on ebinur lake, China. Glob. Ecol. 2020, 24, e01253.

35. Yang, J.; Xie, B.; Zhang, D. Spatio-temporal variation of water yield and its response to precipitation and land use change in the yellow river basin based on invest model. Chin. J. Appl. Ecol. 2020, 31, 2731-2739.

36. Zhao, L.; Xia, J.; Xu, C.-Y.; Wang, Z.; Sobkowiak, L.; Long, C. Evapotranspiration estimation methods in hydrological models. J. Geogr. Sci. 2013, 23, 359-369. [CrossRef]

37. Liu, Y. Scale Dependence of the Relationship between Ecosystem Services. Master's Thesis, Inner Mongolia University, Hohhot, China, 2016. 
38. Zhu, Q.; Guo, J.; Guo, X.; Chen, L.; Han, Y.; Liu, S. Relationship between ecological quality and ecosystem services in a red soil hilly watershed in southern China. Ecol. Indic. 2021, 121, 107119. [CrossRef]

39. Xu, Y.; Zhang, F.; Duan, Z.; Zhang, L.; Kong, X. Calculation method for density and storage of soil organic carbon. Chin. J. Soil Sci. 2005, 36, 836-839.

40. Zhang, Z. Ecosystem Service Evaluation of Dengkou County Based on Invest Model. Master's Thesis, Inner Mongolia Agricultural University, Hohhot, China, 2017.

41. Zhao, R.; Yue, Y.; Yao, Y.; Li, G. Forest carbon storage and its dynamics in inner mongolia. J. Arid Land Res. Environ. 2011, 25, 80-84.

42. Yang, X. Evaluation of Water Production and Water Quality Purification Services in the Arid Regions of Northwest China under the Background of Climate and Land Use Changes. Doctor Dissertation, East China Normal University, Shanghai, China, 2020.

43. Qiu, J.; Turner, M.G. Spatial interactions among ecosystem services in an urbanizing agricultural watershed. Proc. Natl. Acad. Sci. USA 2013, 110, 12149. [CrossRef]

44. Pan, J.; Li, Z. Analysis on trade-offs and synergies of ecosystem services in arid inland river basin. Trans. Chin. Soc. Agric. Eng. 2017, 33, 280-289.

45. Zhang, X.; Niu, J.; Buyantuev, A.; Zhang, Q.; Dong, J.; Kang, S.; Zhang, J. Understanding grassland degradation and restoration from the perspective of ecosystem services: A case study of the xilin river basin in inner mongolia, China. Sustainability 2016, 8, 594. [CrossRef]

46. Hoover, C.M.; Heath, L.S. Potential gains in c storage on productive forestlands in the northeastern united states through stocking management. Ecol. Appl. 2011, 21, 1154-1161. [CrossRef] [PubMed]

47. Kang, T.; Yang, S.; Bu, J.; Chen, J.; Gao, Y. Quantitative assessment for the dynamics of the main ecosystem services and their interactions in the northwestern arid area, China. Sustainability 2020, 12, 803. [CrossRef]

48. Su, C.-H.; Fu, B.-J.; He, C.-S.; Lü, Y.-H. Variation of ecosystem services and human activities: A case study in the yanhe watershed of China. Acta Oecologica. 2012, 44, 46-57. [CrossRef]

49. Di, D.; Wu, Z.; Guo, X.; Lv, C.; Wang, H. Value stream analysis and emergy evaluation of the water resource eco-economic system in the yellow river basin. Water 2019, 11, 710. [CrossRef] 